\title{
The Impact of Public and Developer's Interest on Sustainable Urban Development
}

\author{
Vliv veřejného a developerského zájmu \\ na udržitelný rozvoj území
}

Tereza Ježková, xajezkova@stud.fa.vutbr.cz

Ústav urbanismu, Fakulta architektury, Vysoké učení technické v Brně školitel: doc. Ing. arch. Maxmilián Wittmann, Ph.D.

\begin{abstract}
The contemporary cities' development is concurrently affected by public and business interests and depends mainly on the willingness of these entities to find the common goal they want to reach. By comparing priorities, behaviours and conflicts in case studies, it is possible to determine the changes in the quality of a public space and that of lives of the inhabitants, in the amount of job opportunities and the changes in ecological and hygienic conditions, in case that the developer's plan will be realized or the public interests will be defended to the maximum extent and what is the view of the city that is reflected in the Local Development Plan. The intention is to uncover whether the public, the Local Development Plan, developers or all of them contribute to the desirable city development.
\end{abstract}

KEYWORDS: sustainable development; public interest; developer's interest; urban planning; case study

ABSTRAKT: Rozvoj současných měst je souběžně ovlivňován veřejnými a podnikatelskými zájmy a závisí především na ochotě těchto subjektů najít společný cíl, kterého chtějí dosáhnout. Na př́ípadových studiích je porovnáváním priorit, chování a rozporů možné vysledovat, jak se změní kvalita veřejného prostoru a života obyvatel, množství pracovních příležitostí a ekologické a hygienické podmínky v prrípadě, že bude realizován záměr developera, a v př́padě, že bude v maximální míře hájen veřejný zájem, a jaký je pohled ze strany města, který je reflektován v územním plánu. Záměrem je odhalit, zda k žádoucímu rozvoji lokality či města přispívá veřejnost, ÚP, či naopak developer, prŕípadně všichni. 
KLÍČOVÁ SLOVA: udržitelný rozvoj; veřejný zájem; soukromý zájem; územní plánování; př́padová studie

\section{Úvod}

Ve stavebním zákoně jsou jasně definovány cíle územního plánování, ze kterých jasně vyplývá, že trvale udržitelný rozvoj jde ruku v ruce s nalezením souladu mezi veřejným a soukromým zájmem. „Územní plánování zajištuje předpoklady pro udržitelný rozvoj území soustavným a komplexním řešením účelného využití a prostorového uspořádání územís cílem dosažení obecně prospěšného souladu veřejných a soukromých zájmů na rozvoji území. Za tím účelem sleduje společenský a hospodářský potenciál rozvoje“ (zákon č. 183/2006 Sb., o územním plánování a stavebním řádu).

Tento článek popisuje teoretické prrístupy řešení určené k vyhodnocování váhy vlivu soukromého a veřejného zájmu na trvale udržitelný rozvoj území a následně se zabývá možnostmi využití výsledků výzkumu.

Přehled současného stavu problematiky potvrdil význam a aktuálnost tohoto tématu, zejména nyní, kdy jsou lidé díky sociálním sítím mnohem aktivnější a zakládají občanská sdružení, která se mnohdy nikomu nezodpovídají a která nemusí pokaždé být ve shodě se širším zájmem veřejným, a proto můžeme při přezkoumávání některých př́padů objevit, že námitky a připomínky těchto skupin nejsou vždy relevantní. Oproti tomu existují př́pady, kdy se lidé bránili reálné újmě, kterou jim developerské záměry mohly způsobit, a jejich práva nikdo nehájil. Je pak na městu, aby velmi zodpovědně zvážilo, zda je veřejný zájem v konkrétním př́ípadě silnější než zájem občana, který podal připomínku či námitku.

\section{Přehled současného stavu problematiky}

Developerská výstavba je stále silnějším tématem veřejné debaty. Historicky zde vznikla propast mezi developery a veřejností, a současná atmosféra narovnání vztahů př́liš nepřeje (Andres, 2010). Prosazování projektů bez veřejné diskuze logicky vyústilo v nedůvěru vůči novým stavbám. Město je pak ve svém rozvoji omezené, protože soukromé investice putují za hranice města, kde developeři své záměry realizují snáz (Friedman, 2007). K vyřešení situace by bylo zapotřebí, aby stavebníci komunikovali $s$ veřejností, $s$ předstihem představovali své záměry a naopak aby veřejnost nezastávala názor, že developerské záměry mohou mít na rozvoj území jen negativní dopady, protože i soukromé investice do území mohou mít pozitivní účinky na rozvoj města. 


\section{Veřejný vs. developerský zájem}

Kolize ve vnímání veřejného zájmu je velkým problémem, který ztěžuje celý proces dosahování dohody mezi soukromým developerem a veřejností. Je nutno říct, že pojmy veřejný a soukromý zájem jsou proměnné v čase a co bylo veřejným zájmem $\mathrm{v}$ dobách minulých, dnes už platit nemusí. Asi nejcitovanější definice veřejného zájmu nám ř́ká, že „veřejný zájem je žrejmě tím, co by si lidé vybrali, kdyby viděli jasně a racionálně a jednali nezaujatě a benevolentně“ (Lippman, 1955). Je tedy patrné, že všechny definice jsou pouze obecné a nejednoznačné povahy. Ze všech definic však vyplývá, že veřejný názor by měl být prospěšný všem (Principy a pravidla územního plánování, 2008).

Naproti tomu záměrem soukromého developera je v první řadě docílit zisku. Ale i tento zájem se může prolnout se zájmem veřejným ve chvíli, kdy si soukromý developer uvědomí fakt, že zkultivovaný veřejný prostor, který zahrne do rozsahu svého záměru, mu může finančně zhodnotit investici.

\section{Vymezení okruhu výzkumu}

Ve svém výzkumu považuji za nejprrínosnější zaměřit se přímo na Brno a na další srovnatelně velká evropská města, například Graz a Linz. V rámci Brna je pak nutné vysledovat konkrétní lokality, kde jsou kolize mezi veřejným a soukromým zájmem nejčastější. Jednou z takových lokalit je Masarykova čtvrt', kde je veřejnost zastoupena četnými občanskými hnutími, která pečlivě sledují veškeré soukromé investice plynoucí do území a hájí veřejné zájmy obyvatel, pokud jsou ohroženy. Další oblastí, již lze zahrnout do výzkumu a z níž lze čerpat př́ípadové studie, je historické jádro města, kde může být prosazování soukromých zájmů často zkomplikováno činností památkového odboru a dalších správních institucí, které zastupují zájmy města.

\section{Představa řešení}

V první řadě je nutné vymezit a identifikovat pojmy veřejný zájem, soukromý zájem a udržitelný rozvoj a následně popsat vzájemný vliv veřejného a soukromého zájmu $\mathrm{v}$ rozvoji města.

Historicko-srovnávací analýzou bude zkoumáno, jak se v průběhu času vyvíjela role investora, váha jeho vlivu a váha vlivu veřejného zájmu.

Sběr dat a informací provedeme prostřednictvím místního šetření, pozorování, rozhovorů a dotazování se referentů orgánů činných v územních řízeních, developerů, 
občanských sdružení a účastníků řízení.

Ve vymezeném okruhu výzkumu budou shromážděny a zanalyzovány př́padové studie, na jejichž základě bude vyhodnocen vliv soukromého a veřejného zájmu na udržitelný rozvoj (Hendl, 2016).

Bude porovnáváno, jak se změní hygienické a ekologické podmínky, množství pracovních př́ležitostí a kvalita veřejného prostoru, života obyvatel a životního prostředí $\mathrm{v}$ případě, že bude realizován záměr soukromého investora, a v př́ípadě, že bude hájen veřejný zájem, mnohdy stojící v opozici vůči záměru developera, který v konečném důsledku může docílit zastavení nebo změny developerova záměru. $V$ rámci porovnávání vlivu soukromého a veřejného zájmu by měl být také vyhodnocen pohled z hlediska územního plánu, který zastupuje názor města.

Vyhodnocování vlivů na stav a rozvoj území bude standardní metodikou dle vybraných jevů v oblasti sociální, ekonomické a environmentální a rovněž budou sledovány vlivy na výsledky analýzy silných a slabých stránek, př́iležitostí a hrozeb v území. Výsledek nám odhalí, jakou měrou veřejnost, nebo naopak developer přispívá k udržitelnému rozvoji lokality.

\section{Experiment}

Jednou z metod, které jsou ve výzkumu využívány, je experiment, spočívající ve vytvoření vlastního modelového př́íladu - případové studie Juranka. Juranka je brněnská lokalita o rozloze 112,4 ha nacházející se v katastrálním území Jundrova a Kohoutovic, nad jundrovským říčním údolím řeky Svratky (Katastrální území Jundrov, 2012). Svažité a komplikované území s velkým potenciálem téměř v centru Brna je v současnosti využíváno k rekreaci jako zahrádkářská kolonie. Zastaralý územní plán bohužel lokalitě neumožňuje dále se rozvíjet, chybí dopravní i technická infrastruktura, území je neprostupné, objekty chátrají, pozemky pustnou (Územní plán města Brna, 1994). Současná situace je taková, že ani radnice neví, co si s danou lokalitou počít, a tak ani majitelům pozemků nepovoluje stavbu nových objektů, rozšiřování stávajících objektů a další rozvoj lokality (Náš Jundrov, 2005). Během posledních 20 let bylo v souvislosti s Jurankou zpracováno několik studií možností využití. Dosavadní návrhy však nebyly dostatečně komplexně zpracovány, včetně posouzení všech dopadů zejména na okolní městské části, kterých by se rozvoj této lokality úzce dotýkal (Studie možností využití lokality Juranka, 2000). Absence komunikace a nedostatek informací mezi majiteli pozemků na Jurance, projektanty, kteří návrhy na využití zpracovávali, developery, kteří trpělivě vyčkávají, jak to s Jurankou dopadne, a městskými částmi Jundrov a Kohoutovice vedly k zablokování celého procesu dalšího rozvoje (Kohoutovice.org: zpravodaj k dění v Kohoutovicích, 2014). 
$\mathrm{V}$ rámci experimentu bude vytvořeno několik variant využití dané lokality, v nichž bude reflektován názor skupin, které mají na využití území rozličné názory. Vzniknou tak tř́i varianty. První varianta vychází ze současné situace - varianta 0 , ve které se stanoví předpokládaný vývoj při udržování stávajícího stavu a dále hrozby a dopady na dané území a jeho okolí, jež z tohoto vývoje vyplývají. Druhá varianta odpovídá představám většiny místních obyvatel. Tato varianta umožní rozšiřování zástavby pro rekreační bydlení. Třetí varianta reflektuje požadavky developerů, kteří území chtějí využít pro rezidenční bydlení. Každá z těchto variant prověří, čí záměr jev souladu sprincipy udržitelného rozvojea zda vůbec existuje možnost, že se ujednoho $\mathrm{z}$ řešení veřejný a soukromý názor protnou a dojde $\mathrm{k}$ nalezení společného cíle.

\section{Závěrečné zhodnocení}

Vyhodnocením vlivu veřejného a soukromého zájmu na udržitelný rozvoj na základě porovnání několika př́ípadových studií budeme schopni odhalit, zda k udržitelnému rozvoji města nejlépe přispívá veřejnost, developer, či územní plán. Výsledky by měly přispět k vyhodnocení/nalezení příčin toho, že je upřednostňován právě ten postup, jenž se uplatňuje zřejmě nejvíce. Na modelovém příkladu Juranky si vytvořením několika variant, ve kterých budou postupně reflektovány zájmy obou subjektů - soukromého i veřejného, experimentálně ověříme, kdo a jak přispívá k žádoucímu rozvoji lokality.

Město však podléhá řadě vnějších podmínek, například se - většinou s příchodem nových stran a koalic - mění názory místních představitelů, kteří zastupují veřejné zájmy, mění se ale i potřeby soukromých investorů a zájmových skupin, mění se i vztahy mezi nimi. Základní principy udržitelného rozvoje jsou ovšem stálé a neměnné, a měly by být zohledňovány při prosazování každého záměru, soukromého i veřejného, a měly by eliminovat množství v současnosti převládajících situací, kdy se proti sobě staví „vůle lidu“ a „vůle developerü“.

Př́spěvek vznikl ve vazbě na výzkumný projekt GA ČR 17-26104S Vliv charakteru a umístění urbanistické struktury na udržitelný rozvoj území.

\section{Prameny}

Brno - Jundrov [online]. [cit. 2017-08-31]. Dostupné z: http://www.jundrov.info/ FRIEDMAN, Avi. Sustainable residential development: planning and design for green neighborhoods. New York: McGraw-Hill, c2007. ISBN 0-07-147961-9.

HENDL, Jan. Kvalitativní výzkum: základní teorie, metody a aplikace. Čtvrté, přepracované a rozšířené vydání. Praha: Portál, 2016. ISBN 978-80-262-0982-9.

Katastrální území Brno: podrobné informace. 2012. Územně identifikační registr ČR [online]. [cit. 2017-08-31]. Dostupné z: http://www.uir.cz/katastralni-uzemi- 
-okres/3702/Okres-Brno-mesto

Kohoutovice.org zpravodaj k dění v Kohoutovicích: Juranka, Achtelky [online]. Brno, 2014 [cit. 2017-08-31]. Dostupné z: http://www.kohoutovice.org/juranka-achtelky/ LIPPMANN, Walter. Essays in the public philosophy. Boston: Little, Brown and Company, 1955. Atlantic Monthly Press Book.

Náš Jundrov [online]. [cit. 2017-08-31]. Dostupné z: http://www.nasjundrov.cz/Historie_2005-12-12.htm

Principy a pravidla územního plánování. 2008. MMR, Ústav územního rozvoje.

ROMAN ANDRES. „....ale vždyt to je přeci ten udržitelný rozvoj !!!“. Envigogika [online]. 2010, 5(2) [cit. 2017-01-15]. DOI: 10.14712/18023061.334.

Studie možností využití lokality Juranka [online]. Brno, 2000 [cit. 2017-08-31]. Dostupné z: https://www.brno.cz/sprava-mesta/magistrat-mesta-brna/usek-rozvoje-mesta/odbor-uzemniho-planovani-a-rozvoje/dokumenty/upp/studie-moznosti-vyuziti-lokality-juranka/

Územní plán města Brna [online]. Brno, 1994 [cit. 2017-08-31]. Dostupné z: http://gis. brno.cz/ags/upmb/

Zákon o územním plánování a stavebním řádu. In: č. 183/2006 Sb.. 2006. Dostupné také z: http://business.center.cz/business/pravo/zakony/stavebni/cast3h1.aspx

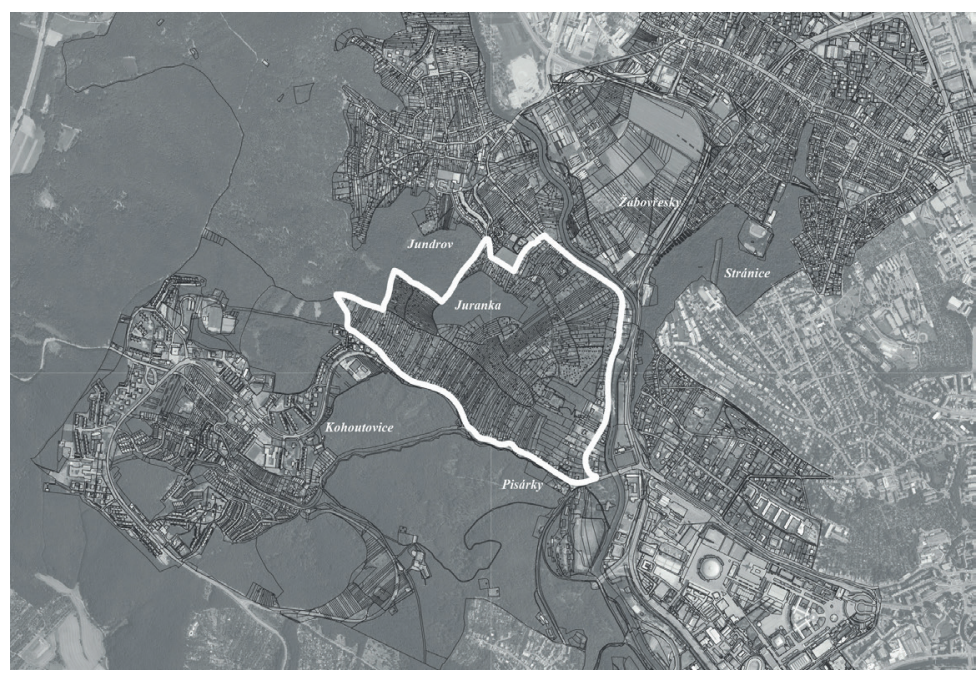

Obr. 1. Širší vztahy lokality Juranka (archiv autora) 